\title{
Judicial measures against workplace harassment in Spain: between progress and resistance
}

\section{Cristóbal Molina Navarrete}

\section{(2) OpenEdition \\ 1 Journals}

Electronic version

URL: https://journals.openedition.org/rdctss/1812

DOI: $10.4000 /$ rdctss. 1812

ISSN: 2262-9815

Publisher

Centre de droit comparé du travail et de la sécurité sociale

Printed version

Date of publication: 1 December 2018

Number of pages: 174-181

ISSN: $2117-4350$

\section{Electronic reference}

Cristóbal Molina Navarrete, "Judicial measures against workplace harassment in Spain: between progress and resistance", Revue de droit comparé du travail et de la sécurité sociale [Online], 4 | 2018, Online since 01 November 2021, connection on 15 November 2021. URL: http://

journals.openedition.org/rdctss/1812 ; DOl: https://doi.org/10.4000/rdctss.1812

\section{(c) $(1) \&$}

Revue de droit comparé du travail et de la sécurité sociale est mise à disposition selon les termes de la Licence Creative Commons Attribution - Pas d'Utilisation Commerciale - Pas de Modification 4.0 International. 


\section{JUDICIAL MEASURES AGAINST WORKPLACE HARASSMENT IN SPAIN: BETWEEN PROGRESS AND RESISTANCE} $00 \Omega 0$

\section{Cristóbal Molina NavarRete}

Professor of Labour and Social Security Law at the University of Jaén (Spain). Director of the Workplace Psychosocial Risks Observatory of Andalusia. Andalusian Workplace Risk Prevention Institute - IAPRL. Seville (Spain).



hile Spain appears to be below the European average for complaints filed for workplace harassment ( $8 \%$ compared with almost 15\% in Europe1), the rulings handed down since 2001 in workplace harassment cases (psychological, sexual, discriminatory, etc.), and more specifically in mobbing cases, number in the thousands. As a result, the Spanish legal system, which does not have specific legislation against workplace psychological harassment except in a criminal context (Article $173 \mathrm{CC}$ ), nevertheless has significant experience in handling such behaviour. This Spanish legal system for workplace harassment, which has its roots in jurisprudence, has rarely failed to do its part, hence the continuing absence of specific labour law in this domain.

However, while the abundance of judicial decisions relating to psychological harassment in the workplace is statistically verifiable, this is no guarantee of effective and efficient legal protection. The vast majority of judgments dismiss the workers' claims, ruling that the case does not constitute real workplace harassment but simply a typical labour dispute or high-tension situation. Since this is a kind of conduct likely to constitute an infringement of fundamental rights (Art. 15 of the Spanish Constitution - CE -: right to personal integrity) or even a felony offence, the majority of judges in Spain take a position of self-restraint, so as to prevent conflicts or situations involving an employer's mere exercise of his legitimate authority from being confused with harassment. This explains why, in general, there has been more resistance than advances from the judiciary in this domain.

1 Vid. EUROFOUND. "La violencia y el acoso laboral en Europa: alcance, repercusiones y políticas" 2015.

https://www.eurofound.europa.eu/es/observatories/eurwork/comparativeinformation/violence-and-harassment-in-european-workplaces-extent-impacts-andpolicies 
The aim of this study is to present a synthetic but complete overview of the state of the case law of the Spanish Supreme Court (hereinafter referred to as the "TS") and lower courts (the Independent Superior Courts of Justice - "TTSSJ") concerning protections against workplace harassment. ${ }^{2}$ In this context, we will examine three aspects of the issue. First, we will outline the judicial concept of harassment as applied in a labour law context in the absence of a specific legal definition, highlighting the constituent elements identified by the courts (I). We will then analyse the legal basis favoured by the Spanish courts in providing protections, namely the fundamental right to integrity (Art. $15 \mathrm{CE}$ ) and the consequences thereof in practice (II). Lastly, we will draw up an inventory of the different legal qualifications that may be assigned to workplace harassment in order to guarantee complete protection against it: prevention, reparation and penalty (III).

\section{I - THE JURISPRUDENTIAL DEFINITION OF WORKPLACE PSYCHOLOGICAL HARASSMENT: THE PREDOMINANCE IN SPANISH JUDICIAL PRACTICE OF THE EXTRA-JUDICIAL OR CLINICAL CONCEPT}

In the absence of a legal definition of psychological harassment at work (Spanish law provides an express definition only of discriminatory harassment, consistent with EU law), Spanish legal doctrine has adopted a concept frequently used in the field of clinical psychology focusing on the domination of individuals, as introduced by the German sociopsychologist H. Leymann and his research in Sweden. STSJ Catalonia 5207/2017 of 12 September gives the following summary: "...psychological harassment or mobbing can be defined as any... psychological violence to which a person is systematically subjected in a professional context that manifests itself in particular by repeated behaviours, words, or attitudes that are detrimental to their dignity or psychological integrity and... impair their working conditions."

This jurisprudential definition parts both from the definition of discriminatory harassment (any behaviour whose object or consequence is to create an intimidating, injurious or degrading environment for one or more persons at work, tending to harm their dignity), and from the technical-scientific perspectives on risk prevention presented in the statements made in technical preventive note 854/2009 of the country's primary technicalscientific body in the field of workplace health and safety (the national workplace safety, health and well-being Institute, INSSBT). This restrictive definition is also the one used for psychological harassment against civil servants in administrative litigation jurisprudence (STS, administrative litigation division, 16 February 2011, inter alia, also STSJ Castile and Leon, administrative litigation division, 356/2017, 24 February, etc.).

Spanish jurisprudence, for example, thus keeps its distance from the role it would need to assume in order for progress to be made: it is adequately adapted neither to recent developments in scientific and preventive thinking, nor to the normative treatment of discriminatory harassment. There are no legitimate grounds for this conceptual dissociation. In practice, the two separate definitions - psychological harassment and discriminatory harassment - frequently overlap. For example, a psychological harassment situation is

2 A more detailed study may be found in C. Molina Navarrette, La tutela judicial frente al acoso moral en el trabajo, Editorial Bomarzo, Albacete, 2018. 
often combined with a sexual harassment situation (STC 250/2007, 17 December), or discrimination based on sex (STSJ Basque Country 1608/2017, 18 July). There are also cases in which psychological harassment is caused by discrimination on grounds of nationality (e.g., STSJ Madrid, 1263/2017, 20 December). Consequently, such a radical dissociation is theoretically and practically inconsistent.

In 17 years, Spanish case law has in no way changed the four essential elements characteristic of workplace psychological harassment:

a) A chronological component: the continuing nature of the prejudicial conduct.

b) A bilateral component: the complex dimension of the conduct, so that the hostile environment is prejudicial both in a "professional sense" for the worker and in a "relational sense" for the organisation.

c) A subjective component: the intention to harm.

d) A consequentiality component: the damage to the worker's psychological health.

In our view, the major problem with this predominant yet erroneous judicial doctrine is that it confuses the structural components of harassment - the creation of an offensive or intimidating environment and its persistent effects over time - with its circumstantial components - the intention to harm and the resulting damage. Without the former, the legal definition of psychological harassment would not exist, whereas the latter serves only to aggravate the legal consequences (cf. STSJ Castile and Leon/Burgos, 218/2014, 8 April, dissenting opinion). This more objective notion of psychological harassment, which relegates the intention to harass to a secondary status, is that adopted by the ruling of the Constitutional Court - STC - TC 250/2007, 17 December, as well as by judicial decisions that prioritise the regularity and intensity component of the behaviour. It is therefore considered that workplace harassment exists: "(...) When the prerogative to organise the work of one's employees... is exercised in a manner likely to cause illness... or anxiety [physical and psychological harm] in... any one of the employees..." (TS, Labour Division, of 11 October 2017, RCUD 3627/14).

\section{II - THE PRIMARY LEGAL GROUNDS FOR JUDICIAL PROTECTION: PROTECTION AGAINST VIOLATIONS OF THE FUNDAMENTAL RIGHT TO PERSONAL INTEGRITY}

Although Spanish judicial practice remains reluctant to establish a legal definition to cover workplace harassment situations, considering them instead merely as exceptionally abnormal or singularly conflictive behaviours, when it does encounter genuine cases of workplace harassment it provides supplementary protections. The reason for this enhanced protection is that these cases are seen in the context of an infringement of fundamental rights, in particular the right to psychophysical and moral integrity (Art. 15 CE; STSJ Galicia, 20 July 2017, Rec. 542/17). Moreover, Spanish jurisprudence and judicial doctrine recognise psychological harassment as a form of conduct that constitutes an infringement of several constitutionally-recognised fundamental rights: personal integrity (Art. $15 \mathrm{CE}$ ), freedom of communication (Art. $20 \mathrm{CE}$ ), discrimination (Art. $14 \mathrm{CE}$ ), honour (Art. $18 \mathrm{CE}$ ) and even judicial protection (Art. $24 \mathrm{CE}$ ), due to the frequency of workplace harassment exercised as a form of retaliation by companies (e.g., STSJ Andalusia/Seville, 3581/2016, 20 December). 
In all cases, constitutional doctrine (STC 160/2007, of 2 July) bases protections against psychological harassment on the right to integrity (Art. $15 \mathrm{CE}$ ); for cases of discriminatory harassment in particular, the basis of the additional protection is given in Art. 14 CE).

Spanish case law has based itself on the notion of unconstitutionality not only for granting special protection in case of harassment, but also for drawing a distinction between harassment and other types of conduct or practices in the context of which protection is not required (labour disputes involving high tension) or where only ordinary legal protections are required. In short, conflictive workplace behaviour that can be characterised as psychological harassment differs from other conflictive practices that create health risks in the workplace, because such behaviour undermines fundamental rights. Attitudes not recognised as harassment can only be handled under "ordinary labour law" (SSTTSSJ Galicia, 11 October 2017, Catalonia 5207/2017 of 12 September, etc.). In other words, in Spanish case law, it is necessary to differentiate psychological harassment from the wide range of normal and abnormal conflicts resolvable under ordinary law (STSJ Andalusia/Seville, 1623/2017, 31 May, classes them all as "normalised staff management impairments"), that is to say:

1. Conflicts related to working conditions (place, time, terms of service, etc.), which constitute a "normalised impairment of the employment relationship" (SSTTSJ Madrid 485/2017, 24 July; Andalusia, 3581/2016, 20 December). Conflict may be an index of harassment, but is never determinant (STSJ Catalonia 2540/17, 19 April)

2. Prolonged occupational pressure situations that causes stress (SSTTSSJ Galicia 1027/2010, 10 March, inter alia)

3. Modes of exercise of employer authority that are unlawful, i.e., abusive or arbitrary. This includes any kind of inappropriate, misplaced or abnormal exercise of the company's powers, oriented towards promoting the "economic interest of the company," but not involving any intent or desire to harm the worker's emotional stability or create a degrading overall environment (STSJ Galicia, 11 October 2017)

4. Tyrannical and humiliating forms of exercise of the employer's managerial powers (or other powers at the company), causing psychological harm to workers individually although exercised against all workers under the employer's authority (SSTSJ Madrid 485/2017, 24 July, op. cit., and 716/2017, 5 July). Nevertheless, if in a general context of conflict, the judge finds "singular acts of humiliation," they may be classed as "abuses of authority constituting harassment" (STSJ PV 1660/2017, 5 September).

Despite the surprising consistency of this jurisprudence, recent Spanish case law suggests that a certain evolution is underway. We will present three:

1. The most important thing in qualifying a case as an infringement of fundamental rights is not the name given to the behaviour but the nature of the behaviour. The employer is legally liable "whether or not the conduct is described as psychological harassment in the 'strict sense' or not, the obligation... to repair the damage caused... does exist..." (STSJ PV 1608/2017, 18 July, STSJ Madrid 581/2014, op. cit.)

2. Any protracted labour conflict situation likely to cause psychosocial harm, absent the preventive intervention required of the employer, constitutes a contractual breach not only under common law - the duty to effectively protect the right to health but also under constitutional law - the duty to protect personal integrity (STSJ PV $1660 / 2017,5$ September). This position, today only in the minority, is equivalent 
to the French jurisprudential doctrine as given in the ruling of the Employment Chamber of the Supreme Court, 6 December 2017, No. 16-10891.

3. We may also note the judicial consideration to a new form of digital harassment at work - related to sexual discrimination - (SSTTSSJ Castile-La Mancha, 443/2016, 8 April and Basque Country 1646/2017, 18 July (involving an employee's harassment of a co-worker using a company phone number and WhatsApp).

\section{III - THE THREE CHANNELS OF JUDICIAL PROTECTION AGAINST WORKPLACE HARASSMENT IN SPANISH LEGAL PRACTICE: PREVENTION, REPARATION AND PENALTY}

Ideally, any legal system includes three types of effective protections against workplace harassment. To wit:

1. Preventive protection techniques. In fact, workplace harassment is a psychosocial type of professional risk that an employer must effectively prevent via the professional risk prevention management system (Art. 14 of the Law on the Prevention of Professional Risks - LPRL)

2. Reparatory protection techniques to address the harms caused by workplace harassment behaviours that were not prevented. The protection against damages caused to workers due to harassment also involves two levels: classification as a work-related illness, with the resulting Social Security benefit in order to compensate for the work stoppages caused, on the one hand, and the employer's civil or professional liability for damages resulting from a serious and culpable breach of the employer's obligations in regard to proper conduct and protection on the other.

3. Channels of punitive protection. These apply when the workplace harassment constitutes a punishable offence, whether of an administrative (harassment as a serious violation by the employer), disciplinary (harassment of a co-worker), or criminal (psychological harassment as a humiliating treatment infraction per Art. 173 $\mathrm{CP})$ nature.

In Spanish legal practice, all these means of protection are applied for the benefit of impacted workers, with different levels of intensity and success. A table summarising this judicial experience of protection, which is quite rich, though its results have been highly variable, would be as follows:

\section{A - HARASSMENT CONSIDERED AS A SPECIFIC PROFESSIONAL RISK UNDER SPANISH JUdICIAL LAW}

In light of the nature of the Spanish legal system, which lacks specific regulations covering psychosocial risks, there were at first doubts about their classification as professional risks (STS, Labour Chamber, 15 December 2018). However, although legislation continues to avoid specifically addressing it, jurisprudence now recognises that harassment does constitute a psychosocial risk that companies must manage (e.g.: STSJ Catalonia 7055/2017, 20 November), which must therefore be included in risk assessments (STS, Labour Chamber, 101/2016, 16 February). Furthermore, if the risk of psychological harassment is not included in the company's prevention policy, even in the absence of prejudice, the employer commits a serious administrative offence, punishable by fines, 
and in case of injury caused to the victim, the company will have to pay, in addition to compensation for damages, a "supplement to Social Security benefits" (Art. 164 of the General Social Security Act - LGSS), which will serve as a kind of "punitive damages" and have a deterrent effect (the employer is made directly responsible for the payment of between 30 and $50 \%$ of the benefits corresponding to the sick leave resulting from the harassment: STS, Labour Chamber, 4 March 2014, RCUD 788/2013)

In Spain, no legal regulation exists requiring employers to establish a preventive intervention policy against workplace psychological harassment - if it is linked to sexual or sexist harassment. However, when such a policy is in place, judicial doctrine tends to consider it as qualifying the employer for an exemption from liability in the event of harassment, or at least as qualifying the employer for a reduction in liability (STSJ Madrid 877/2017, 16 October, STSJ Murcia 446/2017, 26 April), as long as it has been correctly implemented (STSJ Galicia, 9 November 2017)

\section{B - THE HARMS CAUSED BY WORKPLACE HARASSMENT AS WORK-RELATED ILLNESS (ART. 156.2 E) LGSS), AND NOT AS OCCUPATIONAL DISEASE (ART. 157 LGSS)}

Spanish law, which is based on a system of lists, also does not classify the harms or pathologies caused by workplace psychological harassment as occupational diseases, as they are not included in the specific list given for such purpose (Art. 157 LGSS); this is why the benefit of statutory presumption is not granted. However, case law has recognised that they constitute a "work-related illness" - provided that the impacted worker can prove in a trial that there is a causal link with the harassment - thus qualifying the worker for enhanced protections, as if it were a workplace accident situation (Art. 156 LGSS). In this regard as well, from 2011 to the present day, jurisprudence has progressively created a body of work that compensates legal deficiencies to adapt to reality (e.g.: STSJ Castile and Leon, 15 September 2017, Rec. 703/2017, for workers in the private sector; STS, Administrative Litigation Chamber, 15 March 2011, for civil servants).

\section{C - HARASSMENT AS SERIOUS BREACH OF CONTRACT AND EMPLOYER OBLIGATION TO PAY FULL COMPENSATION FOR DAMAGES WITH DETERRENT EFFECT (ART. 183 LRJS)}

In addition to this system of objective liability for damages caused by workplace harassment (or any type of harassment and/or workplace violence, including when perpetrated by third parties), which only requires a finding of harm, regardless of whether or not the employer is found to be culpable, Spanish case law has applied a system of (civil) liability for negligence, whether the employer is the perpetrator of the harassment or has simply failed to stop the harassment being perpetrated by colleagues or third parties against a worker who is under his authority, and therefore under his protection. Art. 183 of the Law on labour courts - LRJS - now provides that any behaviour breaching fundamental rights (not only harassment but also any damages, tangible or intangible) incurs the obligation to provide full compensation for any damages. The obligation to provide compensation also has a deterrent effect, insofar as it serves to encourage the prevention of such cases in the future, whether at the convicted company or any other. Jurisprudence (SSTS, Labour Chamber, 20 September 2011, 8 March 2017, etc.) and autonomous region judicial doctrines (e.g.: STSJ Andalusia/Seville, 1662/2017, 1 June, STSJ Catalonia 2686/2017, 24 April, etc.) do not hesitate to enforce this obligation. 
However, in practice, Spanish courts tend to set reduced compensation amounts (around $€ 12,000$ on average, although these amounts are highly variable - ranging from $€ 6,000$ to $€ 50,000$ ), and the deterrent-preventive effect - not to be confused with actual "punitive damages" 3 - is barely considered. Thus, in this respect, case law alone is unable to adequately guarantee protection or ensure its effectiveness.

\section{D - PSYCHOLOGICAL HARASSMENT AS SERIOUS ADMINISTRATIVE OFFENCE AND/OR HUMILIATING TREATMENT INFRACTION}

A substantial number of workers, critical of the inefficiency of labour law practices - and, for civil servants, of administrative litigation practices - in combating workplace harassment, have filed complaints through administrative law channels (infractions and public penalties upon proposal by the Labour Inspectorate - ITSS - and enforcement by labour authorities) as well as criminal law channels. Repressive administrative labour law does not specifically address psychological harassment either, except in the particular case of discriminatory harassment; but it does include certain general offences (of acute severity) that may be applicable, such as infringement of worker dignity (Art. 8 of the Revised Law on labour offences and sanctions - TRLISOS). In this respect, it is common for the ITSS to punish various entrepreneurial practices that are classed as harassment (Technical Criteria 69/2009) but have nevertheless been regularly approved by the Courts.

For workplace psychological harassment of a greater intensity, the Spanish Criminal Code (CP) has since 2010 included a specific offence, Art. 173.1 CP (for sexual harassment it includes another, Art. 184 CP), and since 2015 it has included an offence for harassment by Internet or "stalking" (Art. 172, ter 2 CP; STS, Criminal Chamber, 324/2017, of 12 July). Criminal jurisprudence includes convictions handed down for workplace harassment on the basis of humiliating treatment infractions (Art. $173 \mathrm{CP}$ ), both before a specific criminal category existed (e.g.: STS, Criminal Chamber, 945/2010, 28 October) and after (e.g.: STS, Criminal Chamber, 325/2017, 19 September). It would thus appear that the possibilities for protection against psychological harassment, at least in Spain, do not vary much whether or not specific legislation exists.

In any case, the extremely low number of criminal convictions for workplace harassment is quite conspicuous, as the vast majority of complaints are dismissed. For a recent example of a conviction, one must refer to the Judgment pronounced by the Provincial Court of Cáceres - Extremadura - 18/2018, 9 January, which found a town mayor guilty of a dual crime, humiliating treatment and violation of psychological integrity, due to acts of harassment (he had denigrated and isolated an official and failed to provide him with any work equipment to perform his duties). He was sentenced to one and a half years' imprisonment - the maximum sentence is two years - and to pay compensation totalling $€ 4,000$. Nevertheless, it should be emphasised that in most cases employee claims made through such channels end up dismissed.

3 According to STJUE of 17 December 2015, Arjona Camacho case, C-407/14. 


\section{Conclusion: a landscape of (rare) points of light and (multiple) shadows}

This review of practices in Spain regarding workplace harassment has given us a window into the richness of the existing body of jurisprudential doctrine. Despite the continuing absence of specific legislation, except in the criminal domain - and some unclear references present in the laws on public employment since 2007, which have rarely been taken into consideration by judges and courts, anti-harassment case law does offer a very broad catalogue of forms of protection for workers impacted by psychological harassment in the workplace. The result of this Spanish judicial activism is the shaping of a strengthened system of protections, as clear and as protective as that which could be offered by the European Union regulatory systems, which in turn do contain specific legislation.

The problem is that, in practice, this theoretical enhanced protection system, conceived on the basis of a jurisprudential adaptation of common techniques for the protection of fundamental rights, is not in fact enforced because it requires conditions that are too exacting to qualify conduct as harassment. From the perspective of case law, real harassment can only occur in situations of intense conflict and in a severely aggravated context, where there is a specific intention to cause harm to the worker. Thus, faced with such a requirement, which has little justification on a regulatory or conceptual level, the vast majority of claims are rejected. So, while Spanish jurisprudence provides a different delimitation than other European countries do (such as, for example, Italian jurisprudence, which requires wilful misrepresentation or a specific intention to cause harm to an individual: Italian Supreme Court, 10 November 2017, n. 26685), it is necessary to advocate a modification to this overly rigid jurisprudential conception of the issue, in order to effectively enforce the obligation to protect against the risk of psychological harassment, as required under the fundamental right to personal integrity in regard to individual health (per Article $15 \mathrm{CE}$ in regard to Art. 43 CE). 